Comparative Advantage of the United States and South Korean Manmade Textile $\underline{\text { Industries }}$

By: Eonyou Shin, Caitlyn Keenan, Elena Karpova

Shin, E., Keenan, C., \& Karpova, E. (2016). Comparative advantage of the U.S. and South Korean manmade fiber-based textile industries. Fashion, Industry and Education, 14(1), 1-9.

Made available courtesy of The Costume Culture Association (복식문화학회) and KISTI: https://doi.org/10.7741/fie.2018.14.1.001

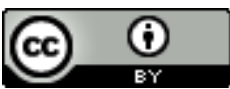

Attribution 4.0 International (CC BY 4.0)

\begin{abstract}
:
This study examined the comparative advantage of manmade textile (MMT) industries in the United States (US) and South Korea (SK). The Revealed Comparative Advantage (RCA) framework was used to assess the MMT industries' performance in both countries from 2004 to 2013. With the recent ratification of the United States-South Korea Free Trade Agreement (KORUS FTA), it is important to understand the current state of these industries. Using UN Comtrade export data, the RCA index values were calculated and analyzed for 27 MMT commodities, three aggregate groups, and the whole industry. It was found that SK had a consistent comparative advantage for the whole industry. Furthermore, SK had a larger number of products with a comparative advantage. The research findings indicate that the MMT industry in SK is likely to outperform the US following the complete ratification of the KORUS FTA.
\end{abstract}

Keywords: KORUS FTA | Manmade textiles | Revealed comparative advantage | South Korea | United States

Article:

$* * *$ Note: Full text of article below 
[Original Article]

Received September 26, 2015

Accepted February 18, 2016

${ }^{\dagger}$ Corresponding author

(eonyoushin@gmail.com)

ORCID

Eonyou Shin

http://orcid.org/0000-0002-6198-7000

Caitlyn Keenan

http://orcid.org/0000-0002-9695-3118

Elena Karpova

http://orcid.org/0000-0002-1612-5989

\section{Comparative Advantage of the United States and South Korean Manmade Textile Industries}

\author{
Eonyou Shin $^{1 \dagger}$, Caitlyn Keenan ${ }^{2}$, and Elena Karpova ${ }^{3}$ \\ ${ }^{1}$ Dept. of Apparel, Events, and Hospitality Management, Iowa State University, USA \\ ${ }^{2}$ School of the Art Institute of Chicago, USA \\ ${ }^{3}$ Dept. of Apparel, Events, and Hospitality Management, Iowa State University, USA
}

\begin{abstract}
This study examined the comparative advantage of manmade textile (MMT) industries in the United States (US) and South Korea (SK). The Revealed Comparative Advantage (RCA) framework was used to assess the MMT industries' performance in both countries from 2004 to 2013. With the recent ratification of the United States-South Korea Free Trade Agreement (KORUS FTA), it is important to understand the current state of these industries. Using UN Comtrade export data, the RCA index values were calculated and analyzed for 27 MMT commodities, three aggregate groups, and the whole industry. It was found that SK had a consistent comparative advantage for the whole industry. Furthermore, SK had a larger number of products with a comparative advantage. The research findings indicate that the MMT industry in SK is likely to outperform the US following the complete ratification of the KORUS FTA.
\end{abstract}

Keywords: KORUS FTA, Manmade textiles, Revealed comparative advantage, South Korea, United States

\section{Introduction}

Recent advancements in technology have increased the market and supply of manmade textiles (MMT) (Allwood, Lauren, Rodriguez, \& Bocken, 2006). According to Lenzing Group (n.d.), synthetic fibers and manmade fibers account for about $70 \%$ of the world fiber market with 89.4 million tons in 2014. The MMT industry has a great potential to create jobs in a developed nation and can help a newly industrialized country upgrade its economy (Chang \& Kilduff, 2002). This study focused on MMTs because it has been one of the fastest growing industries in the global textile complex (Chang \& Kilduff, 2002).

This research investigated trends in comparative advantage (CA) of the United State's (US) and South Korea's (SK) MMT industries. These countries were chosen because the two economies have well established MMT industries (Park \& Kim, 2009). In fact, SK and the US have been among the top MMT exporters. In 2013, SK exported $\$ 6.8$ billion MMTs, which was $52 \%$ of the country's total textile

Copyright@2016, The Costume Culture Association. All rights reserved. 
exports. This made SK the second largest MMT exporter, following China (UN Comtrade, 2015). Similarly, the US exported $\$ 6.7$ billion MMTs in the same year, which was $34 \%$ of the country's total textile exports, securing the top third MMT exporter position in the world (UN Comtrade, 2015).

Furthermore, the United States-South Korea Free Trade Agreement (KORUS FTA) that took effect on March 15, 2012 changes the trade landscape in these two countries. Under the bilateral FTA, many textile and apparel product categories traded between the two countries to the respective markets became duty-free immediately after the agreement was ratified (Office of the United States Trade Representative, 2015). The preferential access to each other's markets will significantly affect the competitiveness of the SK and US MMT industries. The two industries' past and current performance is crucial to understanding the effect of this FTA. To date, no study was found that examined comparative advantages of the US and SK MMT industries. This study addresses the gap in the literature and provides implications for the future competitiveness of the two industries.

\section{Literature Review}

\section{The US Manmade Textile (MMT) Industry}

Research conclusions on the US MMT industry performance were somewhat contradictory. For example, Chi (2010) found the industry's expansion to be fairly modest, whereas Chang and Kilduff (2002) reported a strong growth. Chi (2010) concluded that the US has lost its leading position in the global MMT market because some developing countries, which often use MMT production to further their industrialization, have emerged as very strong competitors. It should be noted that the discussed studies did not assess comparative advantages of the US MMT industry, which is one of the objectives of this research. This investigation is especially important and timely in the recent trade liberalization with SK, a leading producer of MMTs. The KORUS FTA might bring new opportunities and facilitate the growth for the US industry by providing duty-free access to the SK market. However, the same agreement might hinder US MMT industry performance in product categories with lower comparative advantages than goods produced by the SK MMT industry.

\section{South Korean (SK) Manmade Textile (MMT) Industry}

In SK, manufacturing of basic MMT products greatly facilitated the development of the textile industry and helped establish its current competitive position in the global marketplace (Kamiya, 2007). With government support, the industry, first established in the late 1960s, quickly moved to production of advanced technical and smart textiles (Cho \& Cho, 2007). Interestingly, SK's share in the US textile market shrank in the 2000s (Cooper, Manyin, Jurenas, \& Platzer, 2011). Although SK was the third largest source of the US textile imports with $9.8 \%$ of the market share in 1999, SK was the seventh largest exporter to the US with only 3.2\% share by 2009 (Cooper et al., 2011). Lee (1995) showed that SK had a consistently high CA in MMTs between 1965 and 1992. However, no study has examined the recent trends in the SK MMT industry. The current study fills in this gap by examining the comparative advantage of the SK MMT industry in the years leading to and the year after the KORUS FTA ratification.

\section{Comparative Advantage (CA)}

Ricardo and Gonner (1821) introduced the concept of comparative advantage (CA): each country should specialize in production and trade of goods in which it has a relative advantage. Balassa (1965) established the Revealed Comparative Advantage (RCA) index that represents the relative advantage or disadvantage of a certain country in a 
certain class of goods or services as evidenced by trade flow between countries. The RCA index is calculated as follows:

where

$$
\operatorname{RCA}=\left(E_{i j} / E_{i t}\right) /\left(E_{n j} / E_{n t}\right),
$$

$\mathrm{E}_{\mathrm{ij}}$ - export value of commodity $j$ from country $i$;

$\mathrm{E}_{\mathrm{it}}$ - the country $i$ total export of all products;

$\mathrm{E}_{\mathrm{nj}}$ - the world's export of the commodity $j$; and

$E_{n t}$ - the world's total export of all products.

To date, scholars have successfully used the RCA framework to examine CAs of various regional and national industries over different time periods. For example, Richardson and Zhang (2001) used the RCA index to analyze CAs of different industries in the US and its regional markets for the 1980-1995 years. Kilduff and Chi (2006) employed the RCA index to assess patterns of CA in the textile complex of 30 nations over a 42-year period. The authors found that the RCA decreased in textile machinery, manmade fiber, textile, and apparel for high income countries, such as France, Japan, and Switzerland. Among medium income countries, only SK increased its MMT RCA (Kilduff \& Chi, 2006). In the current study, the RCA framework was utilized to examine the comparative advantage of the MMT industries in the US and SK.

\section{Method}

To calculate RCA indices for the US and SK MMT industries, the following export value data were collected from the UN Comtrade database (2015) for the two countries and the world: 27 individual commodities, three aggregate groups, and the total MMT sector (see Table 1). In addition, total countries' and the world's export values of all merchandise were obtained from the same source. The study examined the US and SK MMT industries performance from 2004 to 2013. The period was chosen because 2004 was the year before the Multi Fiber Agreement (MFA) quotas were fully phased out (World Trade Organization, n. d.), and 2013 was the year for which the latest trade data were available for the both countries. The RCA indices for the two countries MMT commodities and industries were examined and interpreted as follows: if the index is greater than one, the country has a CA in that commodity, group, or industry; if the index is less than one, the country does not have a CA (Balassa, 1965).

\section{Results}

Revealed comparative advantage (RCA) indices for the 2004-2013 period for the two countries' MMT commodities and industries are presented in Table 1 for the US and Table 2 for SK. RCA indices that are greater than one, indicating country's comparative advantage, are bolded. The RCA indices for three aggregate groups and each country's total MMT industry are shaded. 
Table 1. RCA values for MMT commodities, commodity groups, and industry for United States

\begin{tabular}{|c|c|c|c|c|c|c|c|c|c|c|}
\hline Commodity & 2004 & 2005 & 2006 & 2007 & 2008 & 2009 & 2010 & 2011 & 2012 & 2013 \\
\hline Manmade filaments & 0.56 & 0.57 & 0.51 & 0.47 & 0.49 & 0.35 & 0.44 & 0.42 & 0.42 & 0.41 \\
\hline Sewing thread & 1.73 & 2.72 & 1.39 & 1.13 & 1.09 & 0.88 & 0.89 & 0.84 & 0.80 & 0.92 \\
\hline Syn. yarn & 0.63 & 0.70 & 0.61 & 0.57 & 0.67 & 0.44 & 0.60 & 0.58 & 0.61 & 0.59 \\
\hline Art. yarn & 0.5 & 0.54 & 0.54 & 0.54 & 0.51 & 0.36 & 1.09 & 1.49 & 1.18 & 1.32 \\
\hline Syn. monofilament & 1.80 & 1.66 & 1.27 & 1.46 & 1.77 & 1.22 & 1.41 & 1.17 & 1.33 & 1.20 \\
\hline Art. monofilament & 0.83 & 1.11 & 0.47 & 0.37 & 0.50 & 0.49 & 0.13 & 0.28 & 0.24 & 0.20 \\
\hline MM yarn & 0.89 & 1.69 & 1.86 & 1.02 & 0.98 & 0.70 & 0.49 & 0.56 & 0.50 & 0.85 \\
\hline Woven syn. fabric & 0.39 & 0.37 & 0.33 & 0.31 & 0.28 & 0.22 & 0.24 & 0.22 & 0.22 & 0.22 \\
\hline Woven art. fabric & 0.61 & 0.43 & 0.40 & 0.23 & 0.21 & 0.14 & 0.22 & 0.17 & 0.18 & 0.14 \\
\hline Manmade staple fibers & 0.73 & 0.76 & 0.75 & 0.79 & 0.83 & 0.78 & 0.82 & 0.81 & 0.80 & 0.82 \\
\hline Syn. filament tow & 0.85 & 0.58 & 0.89 & 0.82 & 0.84 & 0.77 & 0.70 & 0.99 & 0.71 & 0.76 \\
\hline Art. filament tow & 3.06 & 3.36 & 3.63 & 3.83 & 4.35 & 4.27 & 4.44 & 4.41 & 4.27 & 4.20 \\
\hline Syn. unprocessed fibers & 0.97 & 0.91 & 0.87 & 0.83 & 0.57 & 0.53 & 0.70 & 0.70 & 0.65 & 0.61 \\
\hline Art. unprocessed fibers & 0.23 & 0.17 & 0.18 & 0.15 & 0.17 & 0.16 & 0.19 & 0.16 & 0.18 & 0.43 \\
\hline MMF waste, noils & 1.99 & 1.67 & 1.41 & 1.47 & 1.51 & 1.76 & 1.65 & 1.58 & 1.23 & 1.25 \\
\hline Syn. ready to spin fibers & 0.69 & 0.74 & 1.97 & 1.56 & 1.15 & 1.49 & 1.21 & 1.23 & 1.60 & 0.83 \\
\hline Art. ready to spin fibers & 0.39 & 0.46 & 0.61 & 0.28 & 0.36 & 0.29 & 0.22 & 0.35 & 0.29 & 0.31 \\
\hline MM staple fiber sewing thread & 0.50 & 0.56 & 0.51 & 0.43 & 0.43 & 0.30 & 0.44 & 0.40 & 0.44 & 0.45 \\
\hline Syn. staple fiber yarn not retail & 0.32 & 0.46 & 0.49 & 0.52 & 0.74 & 0.65 & 0.78 & 0.84 & 0.79 & 0.77 \\
\hline Art. staple fiber yarn not retail & 0.11 & 0.04 & 0.02 & 0.03 & 0.04 & 0.04 & 0.04 & 0.07 & 0.04 & 0.03 \\
\hline MM staple fiber yarn for retail & 0.52 & 0.58 & 0.92 & 0.83 & 1.25 & 0.91 & 1.15 & 0.75 & 0.66 & 0.54 \\
\hline Woven fabric $>85 \%$ syn. fiber & 0.49 & 0.53 & 0.54 & 0.47 & 0.58 & 0.46 & 0.61 & 0.70 & 0.78 & 0.70 \\
\hline Woven fabric $>85 \%$ syn., $<170 \mathrm{~g} / \mathrm{m}^{2}$ & 0.67 & 0.69 & 0.61 & 0.50 & 0.47 & 0.36 & 0.35 & 0.29 & 0.30 & 0.29 \\
\hline Woven fabric $>85 \%$ syn., $>170 \mathrm{~g} / \mathrm{m}^{2}$ & 1.13 & 1.11 & 0.96 & 0.74 & 0.66 & 0.66 & 0.71 & 0.54 & 0.69 & 0.92 \\
\hline Woven fabric of syn. fiber & 0.31 & 0.27 & 0.29 & 0.24 & 0.28 & 0.22 & 0.22 & 0.21 & 0.22 & 0.27 \\
\hline Woven fabric $<85 \%$ art. fiber & 0.42 & 0.43 & 0.30 & 0.36 & 0.23 & 0.20 & 0.18 & 0.14 & 0.17 & 0.16 \\
\hline $\begin{array}{l}\text { Impregnated, coated or laminated } \\
\text { textile fabric }\end{array}$ & 1.03 & 0.95 & 0.97 & 0.95 & 0.90 & 0.83 & 0.93 & 0.89 & 0.88 & 0.88 \\
\hline Stiffened fabrics & 0.60 & 0.56 & 0.61 & 0.80 & 0.70 & 0.65 & 0.63 & 0.41 & 0.42 & 0.34 \\
\hline Tyre cord & 0.65 & 0.56 & 0.57 & 0.54 & 0.49 & 0.56 & 0.54 & 0.53 & 0.56 & 0.45 \\
\hline Plastic coated fabrics & 0.94 & 0.90 & 0.88 & 0.90 & 0.80 & 0.67 & 0.79 & 0.73 & 0.81 & 0.81 \\
\hline Floor coverings & 0.40 & 0.42 & 0.45 & 0.48 & 0.54 & 0.41 & 0.49 & 0.46 & 0.55 & 0.28 \\
\hline Wall coverings & 0.52 & 0.47 & 0.7 & 0.55 & 0.51 & 0.43 & 0.52 & 0.76 & 0.90 & 0.68 \\
\hline Rubberized fabrics & 1.19 & 1.28 & 1.46 & 1.29 & 1.29 & 1.37 & 1.44 & 1.41 & 1.55 & 1.62 \\
\hline Theatrical backdrops & 2.05 & 2.12 & 1.96 & 1.95 & 2.00 & 1.49 & 1.70 & 1.65 & 1.75 & 1.69 \\
\hline Wicks and gas mantles & 0.78 & 1.14 & 1.5 & 1.69 & 2.06 & 1.29 & 1.31 & 1.07 & 1.10 & 1.22 \\
\hline Tubing & 1.47 & 1.66 & 1.6 & 1.35 & 1.29 & 1.38 & 2.09 & 1.51 & 1.48 & 1.47 \\
\hline Belting & 1.83 & 1.51 & 0.95 & 0.99 & 0.90 & 1.07 & 0.83 & 0.77 & 0.96 & 0.87 \\
\hline Technical textiles & 1.15 & 0.94 & 1.07 & 1.00 & 1.05 & 1.11 & 1.27 & 1.36 & 1.37 & 1.48 \\
\hline Total MMT Industry & 0.71 & 0.72 & 0.68 & 0.68 & 0.70 & 0.59 & 0.68 & 0.66 & 0.68 & 0.68 \\
\hline
\end{tabular}


Table 2. RCA values for MMT commodities, commodity groups, and industry for South Korea

\begin{tabular}{|c|c|c|c|c|c|c|c|c|c|c|}
\hline Commodity & 2004 & 2005 & 2006 & 2007 & 2008 & 2009 & 2010 & 2011 & 2012 & 2013 \\
\hline Manmade filaments & 3.25 & 3.20 & 2.48 & 2.48 & 2.64 & 2.14 & 2.29 & 2.24 & 2.35 & 2.28 \\
\hline Sewing thread & 2.40 & 3.22 & 1.38 & 1.41 & 1.52 & 1.35 & 1.18 & 1.09 & 1.09 & 1.24 \\
\hline Syn. yarn & 3.21 & 3.28 & 2.26 & 2.47 & 2.59 & 1.95 & 2.20 & 2.12 & 2.19 & 2.08 \\
\hline Art. yarn & 0.10 & 0.21 & 0.09 & 0.08 & 0.06 & 0.04 & 0.08 & 0.06 & 0.13 & 0.16 \\
\hline Syn. monofilament & 0.41 & 0.43 & 0.27 & 0.35 & 0.40 & 0.47 & 0.61 & 0.54 & 0.55 & 0.80 \\
\hline Art. monofilament & 0.36 & 0.36 & 0.05 & 0.01 & 0.03 & 0.03 & 0.00 & 0.01 & 0.01 & 0.01 \\
\hline MM yarn & 0.66 & 1.29 & 0.73 & 0.51 & 0.43 & 0.34 & 0.05 & 0.06 & 0.05 & 0.08 \\
\hline Woven syn. fabric & 3.74 & 3.38 & 2.99 & 2.79 & 2.97 & 2.61 & 2.67 & 2.66 & 2.82 & 2.73 \\
\hline Woven art. fabric & 3.47 & 3.60 & 3.51 & 3.87 & 3.88 & 2.32 & 3.54 & 3.19 & 2.89 & 2.85 \\
\hline Manmade staple fibers & 1.92 & 1.84 & 1.71 & 1.80 & 1.64 & 1.40 & 1.56 & 1.54 & 1.61 & 1.63 \\
\hline Syn. filament tow & 6.67 & 4.78 & 2.07 & 2.42 & 2.20 & 1.80 & 1.96 & 1.92 & 1.77 & 1.78 \\
\hline Art. filament tow & 0.53 & 0.59 & 0.62 & 0.44 & 0.44 & 0 & 0.48 & 1.09 & 1.23 & 1.30 \\
\hline Syn. unprocessed fibers & 7.45 & 6.60 & 5.54 & 4.94 & 3.88 & 5.37 & 5.36 & 5.21 & 5.64 & 5.55 \\
\hline Art. unprocessed fibers & 0.13 & 0.12 & 0.03 & 0.02 & 0.08 & 0.06 & 0.14 & 0.03 & 0.03 & 0.04 \\
\hline MMF waste, noils & 0.19 & 0.16 & 0.15 & 0.26 & 0.20 & 0.22 & 0.35 & 0.34 & 0.14 & 0.10 \\
\hline Syn. ready to spin fibers & 0.98 & 1.15 & 1.36 & 1.06 & 1.17 & 1.63 & 1.35 & 0.84 & 0.48 & 0.62 \\
\hline Art. ready to spin fibers & 0.38 & 0.38 & 0.14 & 0.1 & 0.08 & 0.42 & 0.06 & 0.00 & 0.01 & 0.02 \\
\hline MM staple fiber sewing thread & 3.04 & 2.94 & 2.99 & 2.56 & 2.33 & 2.30 & 2.25 & 1.96 & 2.09 & 1.91 \\
\hline Syn. staple fiber yarn not retail & 0.24 & 0.20 & 0.17 & 0.15 & 0.19 & 0.21 & 0.23 & 0.26 & 0.28 & 0.24 \\
\hline Art. staple fiber yarn not retail & 0.60 & 0.78 & 0.83 & 0.97 & 0.9 & 0.91 & 0.93 & 0.64 & 0.86 & 0.66 \\
\hline MM staple fiber yarn for retail & 0.41 & 0.16 & 0.10 & 0.04 & 0.05 & 0.03 & 0.04 & 0.06 & 0.04 & 0.02 \\
\hline Woven fabric $>85 \%$ syn. fiber & 1.68 & 1.75 & 1.54 & 1.21 & 1.16 & 1.14 & 1.19 & 1.29 & 1.46 & 1.69 \\
\hline Woven fabric $>85 \%$ syn., $<170 \mathrm{~g} / \mathrm{m}^{2}$ & 0.68 & 0.63 & 0.52 & 0.4 & 0.36 & 0.26 & 0.31 & 0.22 & 0.17 & 0.16 \\
\hline Woven fabric $>85 \%$ syn., $>170 \mathrm{~g} / \mathrm{m}^{2}$ & 0.64 & 0.50 & 0.47 & 0.36 & 0.35 & 0.39 & 0.32 & 0.28 & 0.33 & 0.33 \\
\hline Woven fabric of syn. fiber & 0.75 & 0.70 & 0.58 & 0.63 & 0.65 & 0.47 & 0.59 & 0.67 & 0.68 & 0.68 \\
\hline Woven fabric $<85 \%$ art. fiber & 2.29 & 2.22 & 2.28 & 2.03 & 1.56 & 1.47 & 1.58 & 1.24 & 0.96 & 0.81 \\
\hline $\begin{array}{l}\text { Impregnated, coated or laminated } \\
\text { textile fabric }\end{array}$ & 2.98 & 2.61 & 2.46 & 2.25 & 2.23 & 1.86 & 1.87 & 1.74 & 1.76 & 1.71 \\
\hline Stiffened fabrics & 0.27 & 0.24 & 0.14 & 0.12 & 0.09 & 0.13 & 0.23 & 0.20 & 0.33 & 0.41 \\
\hline Tyre cord & 4.78 & 4.6 & 4.56 & 4.49 & 4.54 & 4.35 & 4.07 & 3.74 & 3.70 & 3.24 \\
\hline Plastic coated fabrics & 4.39 & 3.82 & 3.59 & 3.17 & 3.05 & 2.38 & 2.26 & 2.05 & 2.06 & 2.11 \\
\hline Floor coverings & 0 & 0 & 0 & 0.01 & 0.01 & 0.01 & 0.01 & 0.02 & 0.02 & 0.02 \\
\hline Wall coverings & 0 & 0.06 & 0.11 & 0.05 & 0.05 & 0.02 & 0.04 & 0.10 & 0.22 & 0.31 \\
\hline Rubberized fabrics & 0.33 & 0.23 & 0.28 & 0.27 & 0.28 & 0.26 & 0.35 & 0.37 & 0.26 & 0.28 \\
\hline Theatrical backdrops & 1.67 & 1.06 & 0.97 & 1.09 & 1.62 & 1.59 & 1.88 & 1.89 & 2.01 & 2.74 \\
\hline Wicks and gas mantles & 0.42 & 0.32 & 0.46 & 0.58 & 1.14 & 1.02 & 0.89 & 0.93 & 2.06 & 1.49 \\
\hline Tubing & 0.12 & 0.19 & 0.18 & 0.15 & 0.12 & 0.14 & 0.63 & 0.08 & 0.07 & 0.01 \\
\hline Belting & 0.25 & 0.26 & 0.37 & 0.30 & 0.20 & 0.22 & 0.20 & 0.14 & 0.19 & 0.23 \\
\hline Technical textiles & 0.21 & 0.22 & 0.23 & 0.26 & 0.38 & 0.32 & 0.32 & 0.37 & 0.58 & 0.46 \\
\hline Total MMT Industry & 2.75 & 2.60 & 2.22 & 2.21 & 2.21 & 1.84 & 1.95 & 1.89 & 1.97 & 1.93 \\
\hline
\end{tabular}


The total US MMT industry had a comparative disadvantage for all ten years, with the RCA index ranging from .59 to .72 . The total SK MMT industry had comparative advantage during the same years, with the index ranging from 1.84 to 2.75. Even though lacking comparative advantage, the US MMT industry has remained relatively stable, with the RCA index decreasing only by $4.2 \%$ from 2004 to 2013. In contrast, comparative advantage of the SK MMT industry decreased by $30 \%$ over the same period (see Figure 1). Unsurprisingly, the lowest RCA indices for both industries were in 2009 as a result of the world's economic crisis.

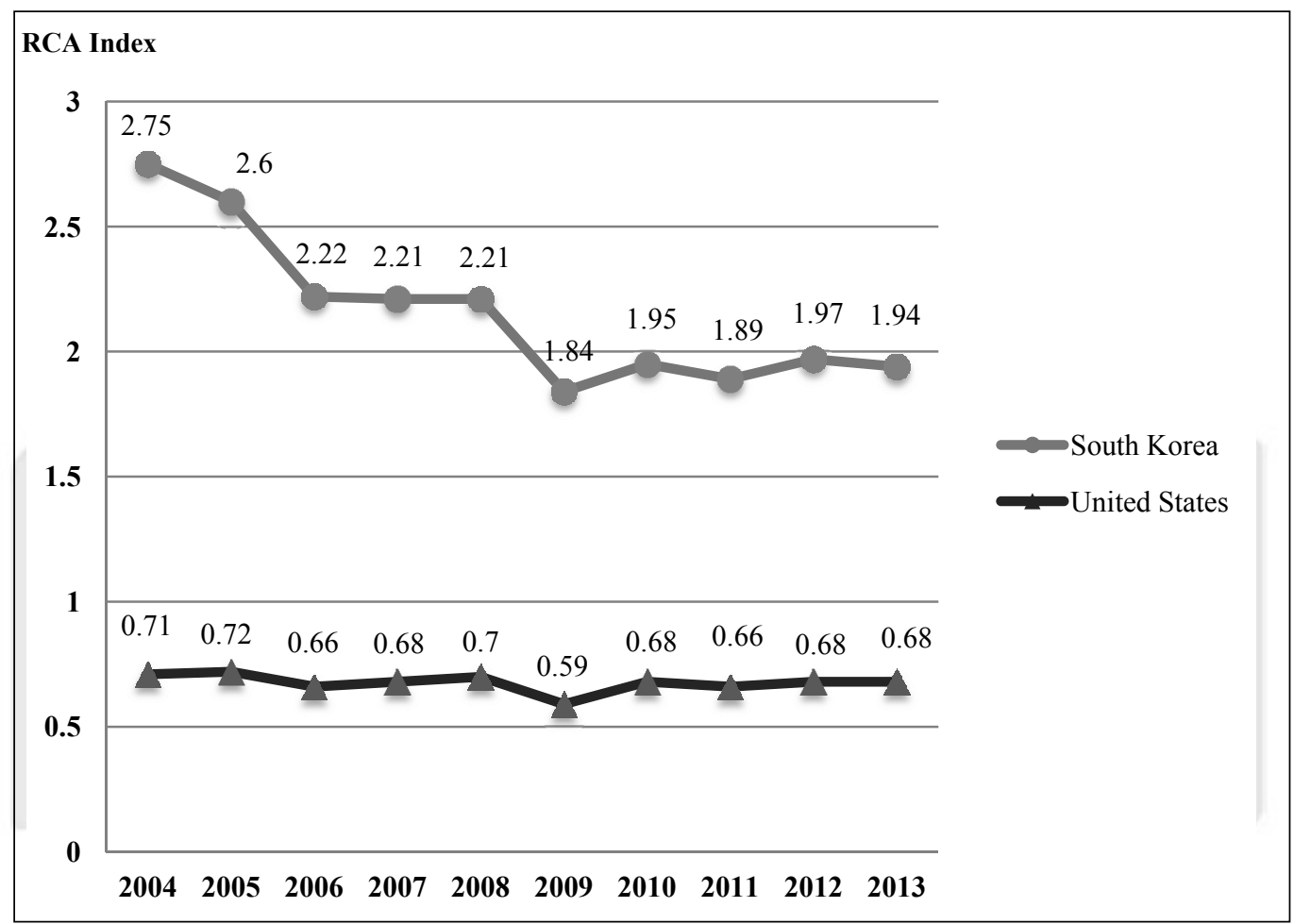

Figure 1. RCA index: Total MMT industry trend, by country

The RCA analysis of the aggregate commodity groups showed that the US industry had a comparative disadvantage for all three groups (filaments, staple fibers, and laminated fabric) over all ten years except manmade filaments group with the RCA index greater than one (1.03) in one year, 2004 (see Figure 2). Further RCA declines were recorded in the two staple fibers and laminated fabrics. The filaments industry group had an increase of $12 \%$ in RCA index between 2004 and 2013. All three aggregate commodity groups in SK had comparative advantage for the whole period of the study (RCA index ranged from 1.40 to 3.25). However, all three groups recorded a decline in RCA index as follows: laminated fabrics by $43 \%$; filaments by $30 \%$; and staple fibers by $15 \%$. 


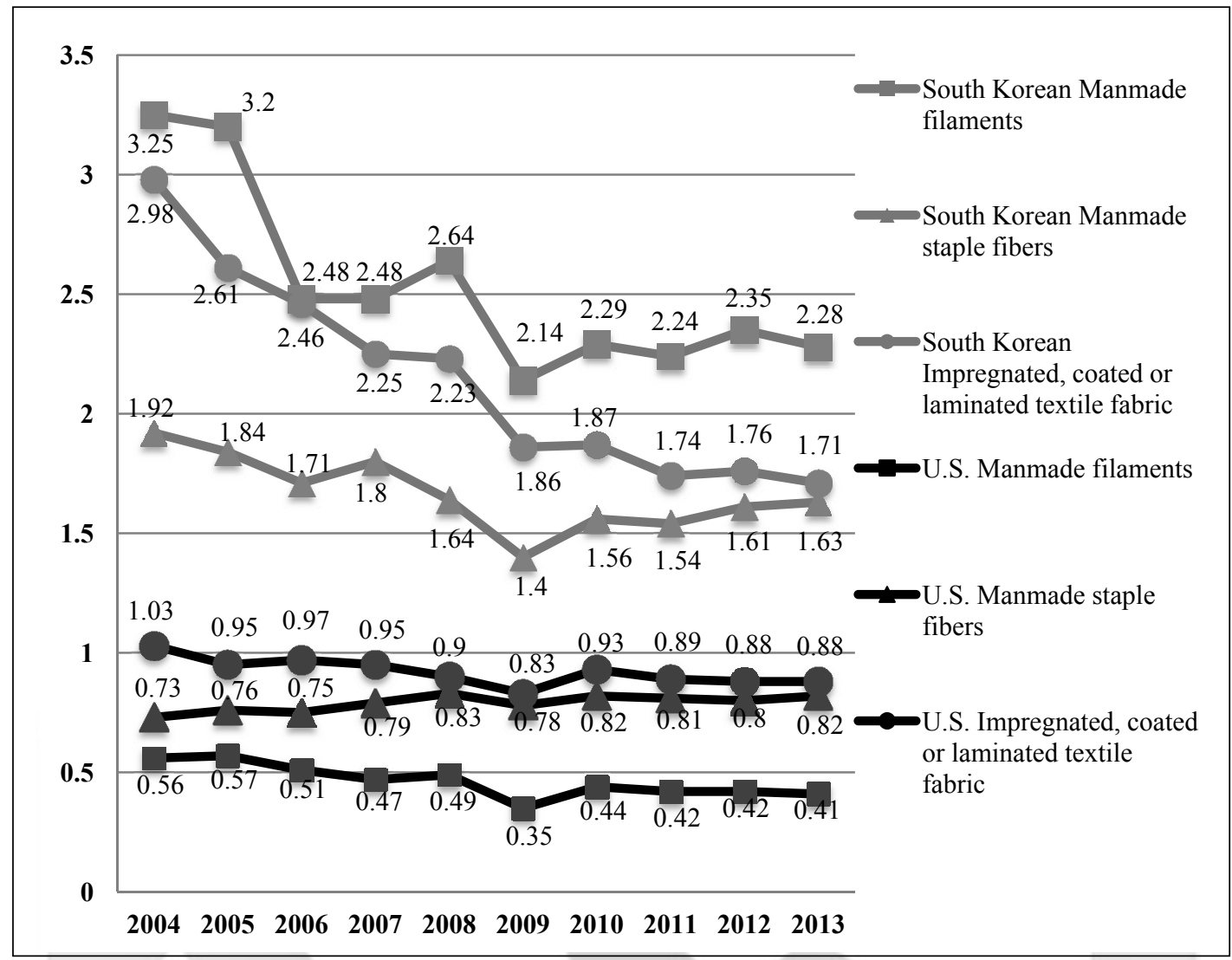

Figure 2. RCA index: Trends for MMT commodity groups, by country

With respect to individual commodities, each country had MMT products with consistent comparative advantage over the ten-year period. Out of the 27 total commodities, the US had eight with a consistent comparative advantage. Of those eight, only one (artificial filament tow) had an RCA value above 2.0 (see Table 1). Of the eight commodities, three strengthen their RCA over the ten-year period: artificial filament tow by $37 \%$, rubberized fabrics by $36 \%$, and technical textiles by $29 \%$. The only other commodity with a RCA growth (164\%) was artificial yarn: the index increased from 0.5 in 2004 to 1.32 in 2013.

Out of 27 total commodities, SK had eleven with consistent comparative advantage over the ten-year period, with indices in the range up to 7.45 and many greater than 2.0 (see Table 2). Despite the decline in the majority of commodities' RCA indices, their comparative advantage remained quite strong and substantially higher than the US RCA indices. Three commodities strengthened their RCA over the ten-year period: artificial filament tow by $135 \%$, theatrical backdrops by $64 \%$, and wicks and gas mantles by $255 \%$. 


\section{Conclusions and Implications}

This study examined trends in competitiveness of manmade textile (MMT) industries the US and South Korea (SK) between 2004 and 2013. The Revealed Comparative Advantage (RCA) framework was used to analyze industry competitiveness. This research indicated that SK had a comparative advantage for the total MMT industry for all ten years (RCA indices were around 2.0), where the US had a comparative disadvantage during the same years (RCA indices were around 0.70 ). Moreover, SK had a comparative advantage in each of the three aggregate industry groups (filaments, staple fibers, and coated/laminated fabrics): RCA indices ranged from 1.40 to 3.25 . The US had a comparative disadvantage in all the three industry groups, with RCA indices ranging from 0.41 to 1.03. Likewise, between 2004 and 2013, SK had more individual commodities (eleven) with a consistent comparative advantage than the US (eight). Furthermore, SK commodities with comparative advantage had much higher values of RCA indices, ranging from 2.0 and 7.0, which indicate a strong comparative advantage. In contrast, most US commodities with a comparative advantage had RCA indices with values less than 2.0. It is important to note that the US and SK have comparative advantages in different commodities, which implies that (1) the industries might not be direct competitors in the global market and (2) each industry might be able to maintain the current comparative advantages under the ratified KORUS FTA.

The research findings show that compared to the US MMT industry, the SK MMT industry is better positioned for maintaining its market share and level of exports with the ratification of the KORUS FTA. However, both countries have demonstrated a decreasing comparative advantage of the domestic MMT industries, with RCA indices declining for the entire industry, all aggregate industry groups, and almost $90 \%$ of individual commodities. This indicates that other countries, like China, for example, might be gaining the MMT world's market share.

Theoretically, this study extended the application of the Revealed Comparative Advantage framework to analyze competitiveness of MMT industries in two developed economies, the US and SK. Practically, the research findings might have important implications for MMT businesses in the two countries. Under the market conditions when the two industries have declining competitiveness and other countries might be increasing their competitiveness in MMT, the US and SK businesses should focus on the product categories with high and/or growing comparative advantage. For example, MMT businesses in the US should emphasize research and product development for commodities such as artificial filament tow, technical textiles, and rubberized fabrics. Similarly, SK companies producing MMT might be more successful in advancing production of commodities with high and/or growing relative comparative advantage, such as artificial filament tow, tire cords, theatrical backdrops, and wicks and gas mantles. These research results are instrumental for the US and SK companies to develop strategic decisions for future expansions and investments in research and product development.

This research was limited to two countries, SK and the US, and addressed a ten-year period, from 2004 to 2013. Finally, the researchers focused on the MMT industry, whereas other studies might expand this investigation to include apparel, footwear, and natural fibers. Further studies are needed to determine emerging leaders in the global MMT market. Future research might employ the RCA index to examine comparative advantages of other developed countries with prominent MMT production, such as Germany or Japan, as well as developing countries that have growing textile industries, such as China and India. 


\section{References}

Allwood, J. M., Lauren, S. E., Rodriguez, C. M., \& Bocken, N. M. P. (2006). Well dressed? The present and future sustainability of clothing and textiles in the United Kingdom. University of Cambridge institute for Manufacturing. Cambridge, England: University of Cambridge Institute for Manufacturing.

Balassa, B. (1965). Trade liberalisation and revealed comparative advantage. Manchester School, 33(2), 99-123. doi: 10.1111/j.1467-9957.1965.tb00050.x

Chang, W., \& Kilduff, P. (2002). The US market for technical textiles. Small Business and Technology Development Center. Retrieved from http://www.sbtdc.org/pdf/textiles.pdf

Chi, T. (2010). An empirical study of trade competitiveness in the U.S. technical textile industry. Journal of Textile and Apparel, Technology and Management, 6(4), 1-19. Retrieved from http://ojs.cnr.ncsu.edu/index.php/ JTATM/article/viewFile/633/733

Cho, G., \& Cho, J. (2007). The technological development of smart-wear for future daily life. Fiber Technology and Industry, 11(2), 111-116.

Cooper, W., Manyin, M., Jurenas, R., \& Platzer, M. (2011). The Proposed U.S.-South Korea Free Trade Agreement (KORUS FTA): Provisions and implications. Congressional Research Service, 1-53. Retrieved from http://digitalcommons.ilr.cornell.edu/key_workplace/813

Kamiya, H. (2007). Changing employment structure in the textile industry of Daegu. Geographische Rundschau International, 3, 28-31.

Kilduff, P., \& Chi, T. (2006). Longitudinal patterns of comparative advantage in the textile complex. Journal of Fashion Marketing and Management, 10(2), 150-168. doi:10.1108/13612020610667478

Lee, J. (1995). Comparative advantage in manufacturing as a determinant of industrialization: The Korean case. World Development, 23(7), 1195-1214. doi:10.1016/0305-750X(95)00039-F

Lenzing Group. (n.d.). The global fiber market in 2014. Retrieved from http://www.lenzing.com/en/investors/equitystory/global-fiber-market.html

Office of the United States Trade Representative. (2015). New opportunities for U.S. exporters under the U.S.-Korea trade agreement. Retrieved from https://ustr.gov/trade-agreements/free-trade-agreements/korus-fta

Park, K. W., \& Kim, M. H. (2009). The industrial relationships in time-varying beta coefficients between Korea and the United States. Applied Economics, 41, 1929-1938. doi:10.1080/00036840601131730

Ricardo, D., \& Gonner, E. C. K. (1821). Principles of political economy and taxation (3rd Ed.). London, England: John Murray.

Richardson, D. J., \& Zhang, C. (2001). Revealing comparative advantage: Chaotic or coherent patterns across time and sector and U.S. trading partner? In M. Blomstrom and L. S. Goldberg (Eds.), Topics in Empirical International Economics: A Festschrift in Honor of Robert E. Lipsey (chapter 7). Retrieved from http://www.nber.org/chapters/c10583.pdf

UN Comtrade. (2015). Database [Data file]. Retrieved from http://www.UNComtrade.org/

Williams, B., Manyin, M., Jurenas, R., \& Platzer, M. (2014). The U.S.-South Korea free trade agreement (KORUS FTA): Provisions and implementation (Research Report No. 7-5700). Retrieved from Federation of American Scientists website: http://fas.org/sgp/crs/row/RL34330.pdf

World Trade Organization (WTO). (n.d.). Textiles: Agreements. Retrieved from http://www.wto.org/english/ tratop_e/texti_e/texintro_e. 